\title{
Determination of Phosphorus-, Copper-, and Zinc-Containing Human Brain Proteins by LA-ICPMS and MALDI-FTICR-MS
}

\author{
J. Sabine Becker, ${ }^{*, \dagger}$ Miroslav Zoriy, ${ }^{\dagger}$ J. Susanne Becker, ${ }^{\ddagger}$ Carola Pickhardt, ${ }^{\dagger}$ Eugen Damoc, ${ }^{\ddagger}$ \\ Gabor Juhacz, $\$$ Miklos Palkovits, $\$$ and Michael Przybylski ${ }^{\ddagger}$
}

Central Division of Analytical Chemistry, Research Centre Jülich, 52425 Jülich, Germany, Laboratory of Analytical Chemistry, Department of Chemistry, University of Konstanz, 78457 Konstanz, Germany, and Laboratory of Neuromorphology, Department of Anatomy, Semmelweis University, Budapest, Hungary

Human brain proteins containing phosphorus, copper, and zinc were detected directly in protein spots in gels of a human brain sample after separation by two-dimensional gel electrophoresis using laser ablation inductively coupled plasma mass spectrometry (LA-ICPMS). A powerful laser ablation system with cooled laser ablation chamber was coupled to a double-focusing sector field ICPMS. The separated protein spots in $2 \mathrm{D}$ gels were fast screened using the optimized microanalytical LA-ICPMS technique measured at medium mass resolution with a focused laser beam (wavelength, $213 \mathrm{~nm}$; diameter of laser crater, $50 \mu \mathrm{m}$; and laser power density, $3 \times 10^{9} \mathrm{~W}$ $\mathrm{cm}^{-2}$ ) with respect to selected three essential elements. Of $\mathbf{1 7 6}$ protein spots in 2D gel from a human brain sample, phosphorus, copper, and zinc were detected in 31,43 , and 49 protein spots, respectively. For the first time, uranium as a naturally occurring radioactive element was found in 20 selected protein spots. The detection limits for $\mathrm{P}, \mathrm{S}, \mathrm{Cu}, \mathrm{Zn}$ and $\mathrm{U}$ were determined in singular protein spots with $0.0013,1.29,0.029,0.063$, and $0.00001 \mathrm{mg} \mathrm{g}^{-1}$, respectively. A combination of LAICPMS with matrix-assisted laser desorption/ionization Fourier transform ion cyclotron resonance mass spectrometry (MALDI-FTICR-MS) was applied for the identification of selected protein spots from human brain protein separated by 2D gel electrophoresis. Combining MALDI-FTICR-MS for the structure analysis of metal- and phosphorus-containing human brain proteins with LAICPMS, the direct analysis of heteroelements on separated proteins in $2 \mathrm{D}$ gels can be performed. For quantification of analytical LA-ICPMS data, the number of sulfur atoms per protein (and following the sulfur concentration) determined by MALDI-FTICR-MS was used for internal standardization. From the known sulfur concentration in protein, the concentration of other heteroelements was calculated. In addition, the number of phosphorylation and the phosphorylation sites of phosphorylated proteins

\footnotetext{
* To whom correspondence should be addressed. E-mail s.becker@fz-juelich.de.

$\dagger$ Research Centre Jülich.

₹ University of Konstanz

$\S$ Semmelweis University Budapest.
}

in the human brain sample detected by LA-ICPMS were determined by MALDI-FTICR-MS. This technique allows the study of posttranslational modifications in human brain proteins.

Proteins containing heteroatoms, such as phosphorylated proteins (phosphoproteins) and metal-containing proteins, play an important and essential role as cofactors in biological systems (e.g., in single cells or cell organelles) and are gaining increasing attention in the field of proteomics. ${ }^{1-4}$ Whereas the absence or deficiency of essential metals or metalloids (such as $\mathrm{Fe}, \mathrm{Cu}$, Se, $\mathrm{Zn}$ ) in proteins results in deficiency diseases, these essential elements can also catalyze cytotoxic reactions. ${ }^{5}$ For example, reversible protein phosphorylation is a key determinant in many fundamental cellular functions, such as survival, differentiation, structural organization, and stress responses, and is relevant for many pathophysiological processes in carcinogenesis or neurodegenerative diseases (e.g., in Alzheimer's ${ }^{6}$ or Parkinson's disease $\left.^{7,8}\right)$. In addition, trace amounts of metals exist in Alzheimer's brain samples. ${ }^{9,10}$ Therefore, the characterization of phosphorus and metal-containing proteins which requires the analysis of phosphorus and metals and the identification of individual proteins is of increasing interest. ${ }^{9,11-17}$ For this challenging task in the

(1) Proefrock, D.; Leonhard, P.; Prange, A. J. Anal. At. Spectrom. 2003, 18, 708.

(2) Jakubowski, N.; Lobinski, R.; Moens, L. J. Anal. At. Spectrom. 2004, 19, $1-4$.

(3) Szpunar, J.; Lobinski, R.; Prange, A. Appl. Spectrosc. 2003, 57, 102A.

(4) Szpunar, J. Analyst 2005, 130, 442.

(5) Finney, L. A.; Halloran, T. V. Science 2003, 300, 931.

(6) Mandelkow, E.-M.; Mandelkow, M. Trends Cell Biol. 1998, 8, 425-427.

(7) Hasegawa, M.; Fujiwara, H.; Nonaka, T.; Wakabayashi, K.; Takahashi, H.; Lee, V. M.; Trojanowski, J. Q.; Mann D.; Iwatsubo, T. J. Biol. Chem. 2002 277, 49071.

(8) Wind, M.; Wegener, A.; Kellner, R.; Lehmann, W. D. Anal. Chem. 2005 77, 1957-1962.

(9) Becker, J. S.; Zoriy, M.; Becker, J. S.; Pickhardt, C.; Przybylski, M. J. Anal. At. Spectrom. 2004, 19, 149.

(10) Cherny, R. A.; Atwood, C. S.; Xilinas, M. E.; Gray, D. N.; Jones, W. D.; McLean, C. A.; Barnham, K. J.; Volitakis, I.; Fraser, F.; Kim, Y.-S.; Huang, X.; Goldstein, L. E.; Moir, R. D.; Lim, J. T.; Beyreuther, K.; Zheng, H.; Tanzi, R. E.; Masters, C. L.; Bush, A. I. Neuron 2001, 30, 665.

(11) Marshall, P.; Heudi, O.; Bains, S.; Freeman, H. N.; Abou-Shakra, F.; Reardon, K. Analyst 2002, 127, 459.

(12) Neilsen, J. L.; Abildtrup, A.; Christensen, J.; Watson, P.; Cox, A.; McLeod, C. W. Spectrochim. Acta, Part B 1998, 53, 339. 
proteomics area (phosphoproteomics and analysis of metalcontaining proteins, respectively), sensitive and powerful analytical techniques combining inorganic and organic mass spectrometry are required. The quantitative determination of phosphorus and metal concentrations in separated protein spots in gels after twodimensional (2D) gel electrophoresis of proteins was performed, for example, by inductively coupled plasma mass spectrometry (ICPMS) after excision of the protein spot from the gel and digestion. ${ }^{15}$ Using ICPMS in combination with ESI-FTICR-MS, electrospray ionization Fourier transform ion cyclotron resonance mass spectrometry, the number of phosphorylations in Tau protein, a target protein in Alzheimer's disease, was determined from normal human brain to be $17 .{ }^{13}$ Disadvantages of the use of ICPMS as an atomic mass spectrometric technique are the more time-consuming excision and digestion of all separated protein spots and a great danger of possible contamination during sample preparation steps. Therefore, the method of choice is the use of laser ablation inductively coupled plasma mass spectrometry (LAICPMS) for fast detection of proteins containing phosphorus and metal ions. For this purpose, LA-ICPMS was applied for the microlocal element analysis of separated protein spots in gels after two-dimensional (2D) gel electrophoresis. ${ }^{9,13,14}$ This powerful screening method for the detection of separated phosphoproteins and metal-containing proteins, (e.g., $\mathrm{Fe}, \mathrm{Zn}, \mathrm{Cu}$ ), directly in $2 \mathrm{D}$ gels by LA-ICPMS was developed for studying posttranslational modifications in proteins of mitochondria. ${ }^{14}$ For quantification of analytical data, sulfur was used as the internal standard element because the sulfur concentration can be derived from the number of cystein residues in the protein investigated as a result of mass spectrometric investigations by MALDI-FTICR-MS. ${ }^{14}$ In addition, quantification of the analytical data from direct microlocal element analysis by LA-ICPMS, and new calibration strategies via $1 \mathrm{D}$ calibration gels or by solution-based calibration strategy in LAICPMS were proposed. . $^{13,14}$

For the analysis of phosphorus and metals in 2D gels by LAICPMS, a cooled laser ablation chamber (using two Peltier elements in serial connection under the target holder made of aluminum) was applied, which results in an improvement of accuracy and precision of analytical data. ${ }^{18}$ Using this experimental arrangement, tracer experiments by means of isotopic-enriched tracers $\left({ }^{54} \mathrm{Fe},{ }^{65} \mathrm{Cu}\right.$, and $\left.{ }^{67} \mathrm{Zn}\right)$ doped to two-dimensional gels of separated Alzheimer's diseased brain proteins after 2D gel electrophoresis to study the formation of proteins containing $\mathrm{Cu}$, $\mathrm{Zn}$ and $\mathrm{Fe}$ in a human brain sample were carried out. ${ }^{19}$ In these tracer experiments, the protein spots were investigated systematically by LA-ICPMS with respect to ${ }^{54} \mathrm{Fe} /{ }^{56} \mathrm{Fe},{ }^{65} \mathrm{Cu} /{ }^{63} \mathrm{Cu}$, and ${ }^{67} \mathrm{Zn} /{ }^{64} \mathrm{Zn}$ isotope ratios. ${ }^{19}$ By isotope

(13) Becker, J. S.; Boulyga, S. F.; Becker, J. Su.; Pickhardt, C.; Damoc, E.; Przybylski, M. Int. J. Mass Spectrom. 2003, 228, 985.

(14) Becker, J. S.; Zoriy, M.; Krause-Buchholz, U.; Becker, J. Su.; Pickhardt, C.; Przybylski, M.; Pompe W.; Rödel, G. J. Anal. At. Spectrom. 2004, 19, 1236.

(15) Becker, J. S.; Boulyga, S. F.; Pickhardt, C.; Becker, J. Su.; Buddrus, S.; Przybylski, M. Anal. Bioanal. Chem. 2003, 375, 561.

(16) Boulyga, S. F.; Pickhardt, C.; Becker, J. Su.; Przybylski, M.; Becker, J. S. Plasma Source Mass Spectrometry; Holland, G., Tanner, S. D., Eds.; Royal Society of Chemistry: Cambridge, 2003; p 54.

(17) Chéry, C. C.; Guenther, D.; Cornelis, R.; Vanhaecke, F.; Moens, L. Electrophoresis 2003, 24, 3305.

(18) Zoriy, M.; Kayser, M.; Pickhardt, C.; Becker, J. S. Int. J. Mass Spectrom. 2005, 142, 297.

(19) Becker, J. Su.; Zoriy, M.; Pickhardt, C.; Przybylski, M.; Becker, J. S. Int. J. Mass Spectrom. 2005, 142, 135. ratio measurements using LA-ICPMS, we found metal-containing proteins with natural isotope composition and enriched isotope ratios. Those protein spots with a natural isotope composition of $\mathrm{Cu}, \mathrm{Zn}$, or Fe are stable enough to survive the reducing conditions during gel electrophoresis. On the other hand, proteins with a changed isotope ratio of metals (isotope enrichments) studied in comparison to the isotope ratio in nature demonstrate the accumulation of enriched spikes on metal-containing protein complexes during the tracer experiments in $2 \mathrm{D}$ gels. ${ }^{19}$

To solve the most important inherent problem in LA-ICPMS, that is, the appearance of isobaric interferences (e.g., the determination of phosphorus, copper, and zinc is disturbed by the formation of molecular ions such as ${ }^{15} \mathrm{~N}^{16} \mathrm{O}^{+},{ }^{14} \mathrm{~N}^{17} \mathrm{O}^{+}$, and ${ }^{14} \mathrm{~N}^{16} \mathrm{O}^{1} \mathrm{H}^{+}$at ${ }^{31} \mathrm{P}^{+} ;{ }^{16} \mathrm{O}_{2}{ }^{+}$at ${ }^{32} \mathrm{~S}^{+} ;{ }^{40} \mathrm{Ar}^{16} \mathrm{O}^{+}$at ${ }^{56} \mathrm{Fe}^{+} ;{ }^{40} \mathrm{Ar}^{23} \mathrm{Na}^{+}$at ${ }^{63} \mathrm{Cu}^{+}$; ${ }^{40} \mathrm{Ar}^{25} \mathrm{Mg}^{+}$at ${ }^{65} \mathrm{Cu}^{+}$; and ${ }^{32} \mathrm{~S}_{2}{ }^{+}$at ${ }^{64} \mathrm{Zn}^{+}$, respectively), a double-focusing sector field mass spectrometer with an inductively coupled plasma ion source at medium mass resolution $(m / \Delta m \sim$ 4400) was applied for the separation of isobaric interferences of molecular ions from analyte ions in small amounts of protein samples. ${ }^{13,14}$

In addition, to determine the phosphorus and metal concentrations by element analytical method using LA-ICPMS, the identification and structure analysis of the investigated proteins, including the determination of the sequence of amino acids, are necessary by organic mass spectrometry, including the analysis of posttranslational modifications such as glycosylation, fatty acylation, and phosphorylation. For protein identification, organic mass spectrometry methods that employ soft ionization techniques (matrix-assisted laser desorption/ionization, MALDI, or electrospray ionization, ESI) permit the identification of large biomolecules, such as proteins, after the excision and tryptic digestion of the protein spot from a 2D gel.11,20,21 Subsequent analysis of the derived peptide mixture by organic mass spectrometry yields results on the posttranslational modifications of proteins, for example, phosphorylation or the formation of metal-bonding proteins. ${ }^{9,22-24}$ Although MALDI and ESI mass spectrometry can be used for the identification of phosphorylation sites in proteins, these techniques cannot provide direct quantitative determinations of phosphorus and metals in biological samples; therefore, a combination with atomic mass spectrometry is required.

The aim of this work is to identify phosphorus- and metalcontaining proteins and to analyze the phosphorylation of proteins in a complex protein mixture in human brain samples (somatomotor cortex). Therefore, a fast, direct screening technique with a lateral resolution in the $10-50 \mu \mathrm{m}$ range was applied for the quasisimultaneous multielement determination of phosphorus and metal content in small protein spots in two-dimensional gels by LA-ICPMS. In addition to copper and zinc as essential elements, uranium as an example of a nonessential naturally occurring toxic and radioactive element will be measured. The combination of

(20) Fligge, T. A.; Reinhard, C.; Harter, C.; Wieland F. T.; Przybylski, M. Biochemistry 2000, 8491.

(21) Rossier, J. S.; Youhnovski, N.; Lion, N.; Damoc, E.; Becker, J. S.; Reymond, F.; Girault, H. H.; Przybylski, M. Angew. Chem. Int. Ed. 2003, 42, 55.

(22) Davies, M. J.; Dean, R. T.; Davies, D. Radical-Mediated Protein Oxidation: From Chemistry to Medicine; Oxford University Press: Oxford, UK, 1998.

(23) Sefton, B. M.; Hunter, T. E. Protein Phosphorylation, 1st ed.; Academic Press: San Diego, CA, 1998

(24) Emmett, M. R.; White, F. M.; Hendrickson, C. L.; Shi, S. D.; Marshall, A G. J. Am. Soc. Mass Spectrom. 1998, 9, 333. 


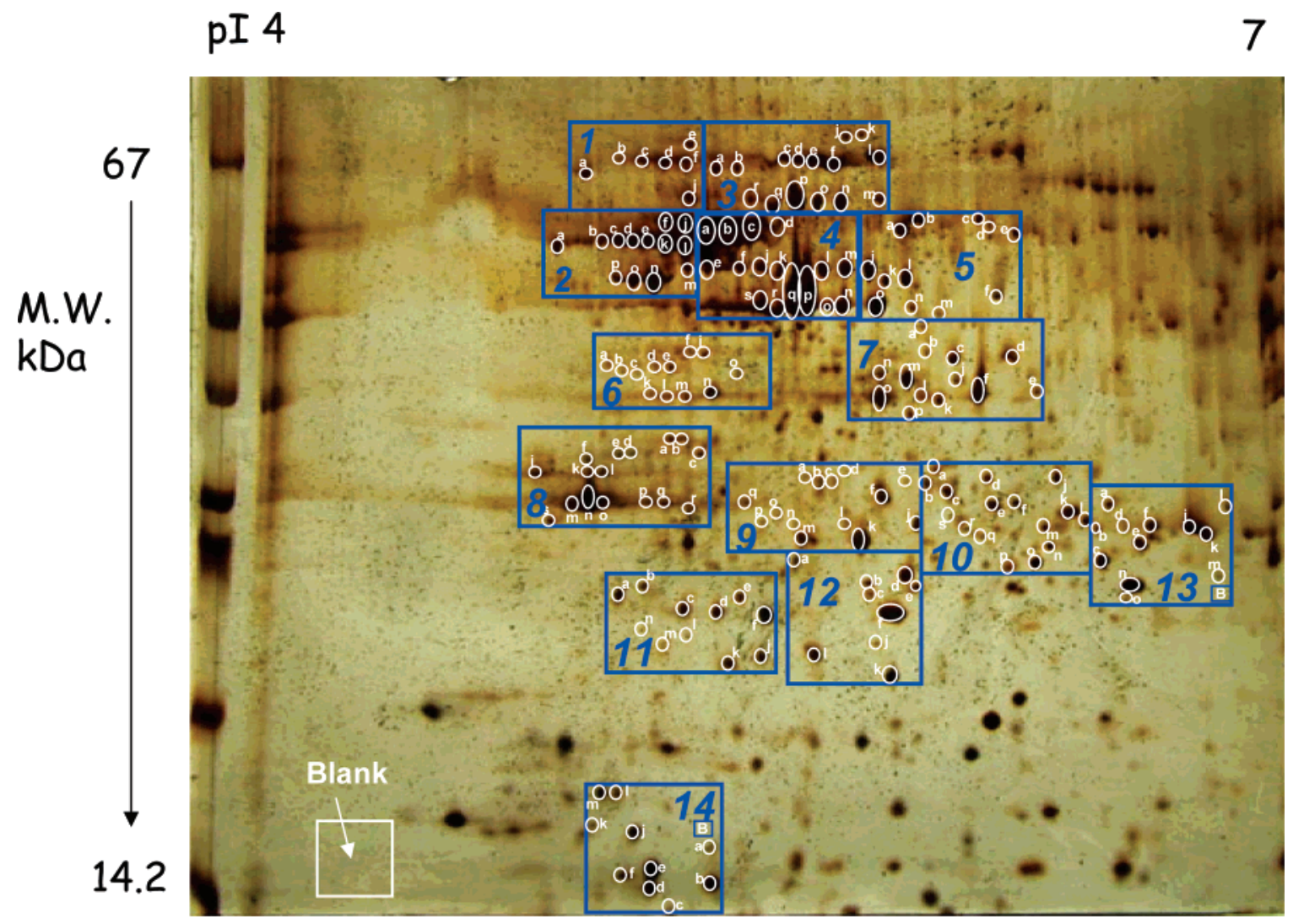

Figure 1. Two-dimensional gel after electrophoretic separation of proteins from human brain sample (somatomotor cortex) using an IPG strip 4-7 for the first dimension and an SDS-PAGE for the second dimension; 176 separated protein spots were analyzed.

LA-ICPMS with high-resolution MALDI-FTICR-MS will be used as a suitable tool for protein identification and quantification of protein phosphorylation as well as of metal concentrations.

\section{EXPERIMENTAL SECTION}

LA-ICPMS Instrumentation. A double-focusing sector field ICPMS (ELEMENT, Thermo Electron, Bremen, Germany) coupled to a powerful Nd:YAG laser ablation system Ablascop (Bioptic, Berlin) operating at wavelength, $213 \mathrm{~nm}$; diameter of laser crater, $50 \mu \mathrm{m}$; and laser power density, $3 \times 10^{9} \mathrm{~W} \mathrm{~cm}^{-2}$ was used for the microlocal analysis of phosphorus, metals, and sulfur in protein spots in 2D gel. The laser beam was focused on separated protein spots, the ablated material was transported by argon as a carrier gas into the inductively coupled plasma (ICP). The ICP torch was shielded with a grounded platinum electrode (GuardElectrode, Thermo Electron, Bremen). For optimization of experimental parameters, an ultrasonic nebulizer (USN, CETAC Technologies Inc., Omaha, NB) was used, which was coupled on-line to the laser ablation chamber. The ions formed in the ICP were extracted in the sector-field mass spectrometer and separated according to their mass-to-charge ratios. To separate possible interfering molecular ions from the atomic ions ${ }^{31} \mathrm{P}^{+},{ }^{32} \mathrm{~S}^{+},{ }^{63} \mathrm{Cu}^{+}$, and ${ }^{64} \mathrm{Zn}^{+}$, all LA-ICPMS measurements were performed at medium mass resolution $(m / \Delta m$ of 4400$)$. In addition, uranium was analyzed simultaneously at medium mass resolution by LA-ICPMS, even though no interferences occur at mass $238 \mathrm{u}$, because only a small amount of protein is available in separated spots, and therefore, a second measurement at low mass resolution is not possible. The optimized experimental parameters of the LA-ICPMS measurements are summarized in Table 1.

\section{Table 1. Optimized Experimental Parameters of LA-ICPMS}

$\begin{array}{ll} & \\ \text { rf power } & \text { ICPMS } \\ \text { cooling gas flow rate } & 1200 \\ \text { auxiliary gas flow rate } & 18 \mathrm{~L} \mathrm{~min}^{-1} \\ \text { nebulizer (carrier) gas flow rate } & 1 \mathrm{~L} \mathrm{~min}^{-1} \\ \text { mass resolution }(m / \Delta m) & 1.2 \mathrm{~L} \mathrm{~min}^{-1} \\ \text { no. of runs (pass) } & 4400 \\ \text { analysis time per spot } & 150(1) \\ \end{array}$

\begin{tabular}{ll}
\multicolumn{1}{c}{ Laser Ablation } & \\
laser ablation system & Ablascope \\
wavelength & $213 \mathrm{~nm}$ \\
laser power density & $3 \times 10^{9} \mathrm{~W} \mathrm{~cm}^{-2}$ \\
laser energy per pulse & $6 \mathrm{~mJ}$ \\
repetition frequency & $20 \mathrm{~Hz}$ \\
spot diameter & $50 \mu \mathrm{m}$
\end{tabular}

LA-ICPMS Measurements and Quantification Procedure. The separated protein spots in the 2D gels (Figure 1) were screened using LA-ICPMS at mass-to-charge ratios of 31, 32, 63, 64 , and 238 with respect to the measurement of $\mathrm{P}^{+}, \mathrm{S}^{+}, \mathrm{Cu}^{+}, \mathrm{Zn}^{+}$, and $\mathrm{U}^{+}$ion intensities. Several protein spots containing $\mathrm{P}, \mathrm{S}, \mathrm{Cu}$, $\mathrm{Zn}$, and $\mathrm{U}$ were selected for further analytical studies on an additional 2D gel. The quantification procedure was performed by measuring ion intensities of analytes in the protein spots, as described in a previous paper. ${ }^{14}$ The element concentration in the protein spots was determined with respect to the known sulfur concentration (if sulfur-containing protein was identified by MALDI-FTICR-MS). For quantification of analytical LA-ICPMS data, the number of cystein residues and following the number 
of sulfur atoms per protein were measured by MALDI-FTICRMS. By this means sulfur as internal standard element was used. From the known sulfur concentration in the protein, the concentration of other heteroelements was calculated, as described in a previous paper. ${ }^{14}$

The concentrations of these elements in the blank gel marked in Figure 1 were determined after microwave digestion via measurement of the background intensity of ${ }^{31} \mathrm{P}^{+},{ }^{32} \mathrm{~S}^{+},{ }^{63} \mathrm{Cu}^{+}$, ${ }^{64} \mathrm{Zn}^{+}$, and ${ }^{238} \mathrm{U}^{+}$by external calibration using ICPMS.

MALDI-FTICR-MS Instrumentation and Measurements. MALDI-FTICR-MS measurements on protein samples after separation by $2 \mathrm{D}$ gel electrophoresis and subsequent tryptic in-gel digestion were performed with a Bruker Apex II FTICR instrument equipped with an actively shielded 7-T superconducting magnet, a cylindrical infinity ICR analyzer cell, and an external MALDI ion source. A detailed description of this instrumentation has been given elsewhere. ${ }^{19,20}$ The MALDI source with pulsed nitrogen laser is operated at $337 \mathrm{~nm}$, and ions are directly desorbed into a hexapole ion guide while being cooled during formation using $\mathrm{Ar}$ as the collision gas. Ions generated by 20 laser shots were accumulated in the hexapole at $15 \mathrm{~V}$ and extracted at $7 \mathrm{~V}$ into the analyzer cell. A $100 \mathrm{mg} / \mathrm{mL}$ solution of 2,5-dihydroxybenzoic acid (DHB, Aldrich, Germany) in acetonitrile/0.1\% trifluoroacetic acid in water (2:1) was used as the matrix. A volume of $0.5 \mu \mathrm{L}$ of matrix solution and $0.5 \mu \mathrm{L}$ of sample solution was mixed on the stainless steel MALDI sample target and allowed to dry.

Samples and Sample Preparation. The isolated proteins from a human brain sample (somatomotor cortex) were analyzed directly with respect to phosphorus, sulfur, copper, zinc, and uranium content by LA-ICPMS after 2D gel electrophoresis. Proteins were digested with trypsin (Progema, Mannheim, Germany) and analyzed by MALDI-FTICR-MS as previously described. ${ }^{14}$

Standards and Reagents. Concentrated nitric acid of supra grade purity from Merck (Darmstadt, Germany) was used for sample digestion of gel blank. Phosphorus, sulfur, copper, zinc, and uranium standard stock solutions for the calibration procedures were obtained from Merck (Darmstadt, Germany) and from the National Institute of Standards and Technology (NIST, Gaithersburg, MD). For all dilutions, deionized Milli-Q water (18 $\mathrm{M} \Omega$ ) was obtained from a Millipore (Millipore Bedford, MA) MilliQ-Plus water purifier.

Protein Separation by Two-Dimensional Gel Electrophoresis. To isolate the soluble and membrane proteins from human brain samples, a piece of somatomotor cortex was taken, and a buffer, containing $\mathrm{NaCl}$, Tris- $\mathrm{HCl}$ buffer (Merck, Darmstadt, Germany), and protease inhibitors (e.g. aprotinin, antipain, leupeptin, pepstatin, from Sigma, Deisenhofen, Germany) was added, and the mixture was ultracentrifuged. The pellet was resuspended in the buffer, which also included Triton X-100 (Sigma, Deisenhofen, Germany), shaken, and centrifuged. The proteins in the resuspended pellet were concentrated by acetone precipitation.

The isolated brain proteins from human brain dissolved in rehydration buffer (8 M Harnstoff, 2\% (w/v) CHAPS, 2\% (v/v) Pharmalyt 4-7 (SERVA Electrophoresis GmbH, Heidelberg, Germany), $15 \mathrm{mM}$ DTT) were rehydrated overnight on IPG strips 4-7 (BioRad, Muenchen, Germany). In the first step, the proteins were separated by isoelectric focusing, separating the proteins according to their isoelectric point in the Multiphor II instrument (Amersham Bioscience Europe GmbH, Germany). Separation of the complex constituents was performed by a second dimension (SDS-PAGE) to separate the proteins according to their molecular weight in a polyacrylamide gel, $20 \mathrm{~cm} \times 20 \mathrm{~cm}$, described by Laemmli. ${ }^{25}$ A molecular weight marker (Merck, Darmstadt, Germany) with a mass range from 14.2 to $67 \mathrm{kDa}$ was used during the second dimension of the gel electrophoresis.

Proteins were stained by the silver staining technique described by Heukeshoven and Dernick ${ }^{26}$ using silver nitrate and calcium carbonate together with formaldehyde (Merck, Darmstadt, Germany) for LA-ICPMS and for MALDI-FTICR-MS. All protein separations were performed in duplicate by using the selected separated proteins in parallel from one gel for analysis of $\mathrm{P}, \mathrm{S}, \mathrm{Cu}, \mathrm{Zn}$, and $\mathrm{U}$ directly by LA-ICPMS and the second gel for identification of proteins by MALDI-FTICR-MS. Phosphorus and metal-containing protein spots selected by LA-ICPMS were cut out and digested with trypsin (Progema, Mannheim, Germany) and analyzed with MALDI-FTICR-MS as described previously. ${ }^{14}$

\section{RESULTS AND DISCUSSION}

Separation of Human Proteins. Human protein complexes were separated by two-dimensional gel electrophoresis as described in the Experimental Section. 2D gels were stained by the silver staining technique. In Figure 1, a two-dimensional gel is shown after the separation of proteins from a human brain sample (somatomotor cortex) by 2D gel electrophoresis. The $\mathrm{P}$ and metal contents in proteins with a molecular weight were determined mass spectrometrically.

Screening of Protein Spots in Two-Dimensional Gels by LA-ICPMS. Separated protein spots were subjected to a systematic screen for various elements using an analytical screening technique by means of LA-ICPMS. ${ }^{14}$ A total of 176 well-separated protein spots in 14 selected parts (cut out) marked in Figure 1 were analyzed by LA-ICPMS with respect to five selected analytes, including $\mathrm{S}$ for internal standardization. In most of the protein spots (e.g., in spot numbers $1 \mathrm{a}-\mathrm{d}, 1 \mathrm{f}, 1 \mathrm{j}, 2 \mathrm{a}-\mathrm{c}, 3 \mathrm{c}, 4 \mathrm{f}, 5 \mathrm{~b}, 6 \mathrm{a}, 6 \mathrm{~b}$, 6e, 6f, 7a-c, 8e, 8f, 8-1, 9-1, 10a-d, 12b, 13a, 13b, 14a, and 14b) none of the elements of interest $(\mathrm{P}, \mathrm{Cu}, \mathrm{Zn}$, and $\mathrm{U}$ ) was found. If phosphorus was measured in individual protein spots, $\mathrm{Cu}$ and $\mathrm{Zn}$ were also often found by LA-ICPMS at higher ion intensities in comparison to phosphorus. In several proteins, only selected elements were present (e.g., $\mathrm{P}$ in $10 \mathrm{e}$ and $10 \mathrm{f}$; $\mathrm{Cu}$ in $1 \mathrm{j}$; $\mathrm{Zn}$ in 3c; $\mathrm{P}$ and $\mathrm{Zn}$ in 3f; $\mathrm{Zn}$ in $12 \mathrm{c}$; $\mathrm{U}$ in $10 \mathrm{a}$ ), or the ion intensities of ${ }^{31} \mathrm{P}^{+}$, ${ }^{64} \mathrm{Zn}^{+},{ }^{63} \mathrm{Cu}^{+}$, or ${ }^{238} \mathrm{U}^{+}$were relatively low (near the background signal). In some protein spots (e.g., $\mathrm{Cu}$ and $\mathrm{Zn}$ in 21 and $9 \mathrm{~d}$; $\mathrm{P}$ in $9 \mathrm{~b} ; \mathrm{P}, \mathrm{Cu}, \mathrm{Zn}$, and $\mathrm{U}$ in $12 \mathrm{a}$ ), and in some, high ion intensities of the analytes were measured. We attempted to use MALDI-FTICRMS to identify phosphorylated protein spots containing metals detected by LA-ICPMS. From 176 spots studied in 2D gel, 31 proteins containing phosphorus were found; 43 proteins contained $\mathrm{Cu}$; and in 49 protein spots, $\mathrm{Zn}$ was measured, some at high ion intensities (e.g., in spots 2g, 21, 5a, 9b, 9d, 10j, 12a, and 14c). In 20 protein spots, uranium was detected. The highest ${ }^{238} \mathrm{U}^{+}$ion intensity of $\sim 4000$ cps was measured in protein spot 11e (see

(25) Laemmli, U. K. Nature 1970, 277, 680.

(26) Heukeshoven, J.; Dernick, R. Electrophoresis 1985, 6, 103. 


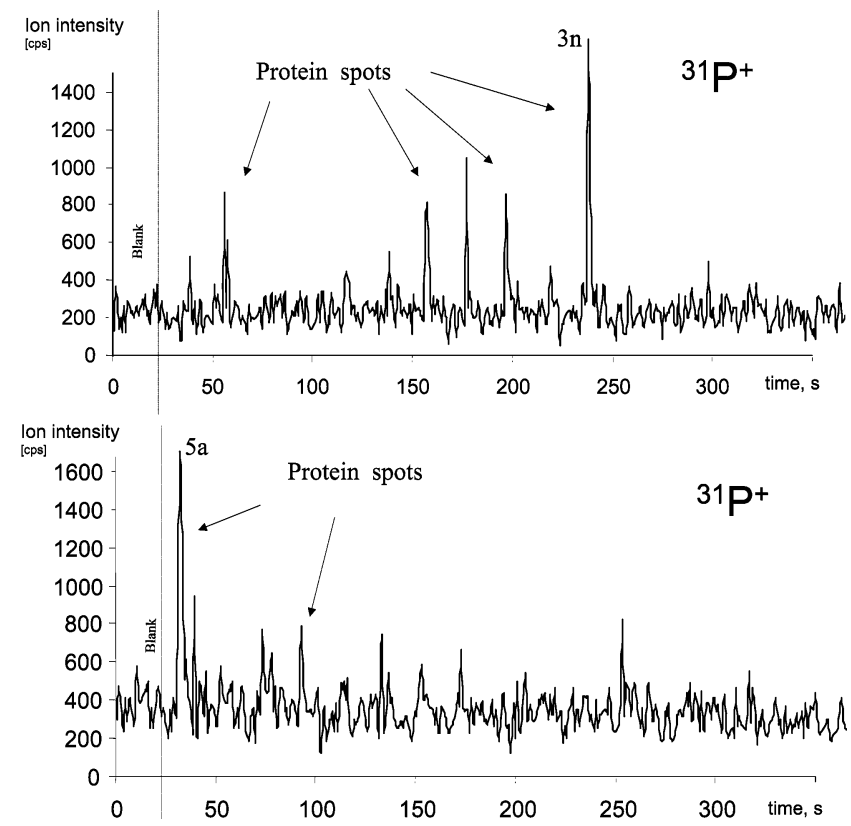

Figure 2. Transient signals of ${ }^{31} \mathrm{P}^{+}$measured in separated protein spots of human brain sample in cuts 3 and 5 measured by sector field LA-ICPMS at mass resolution $m / \Delta m=4400$.

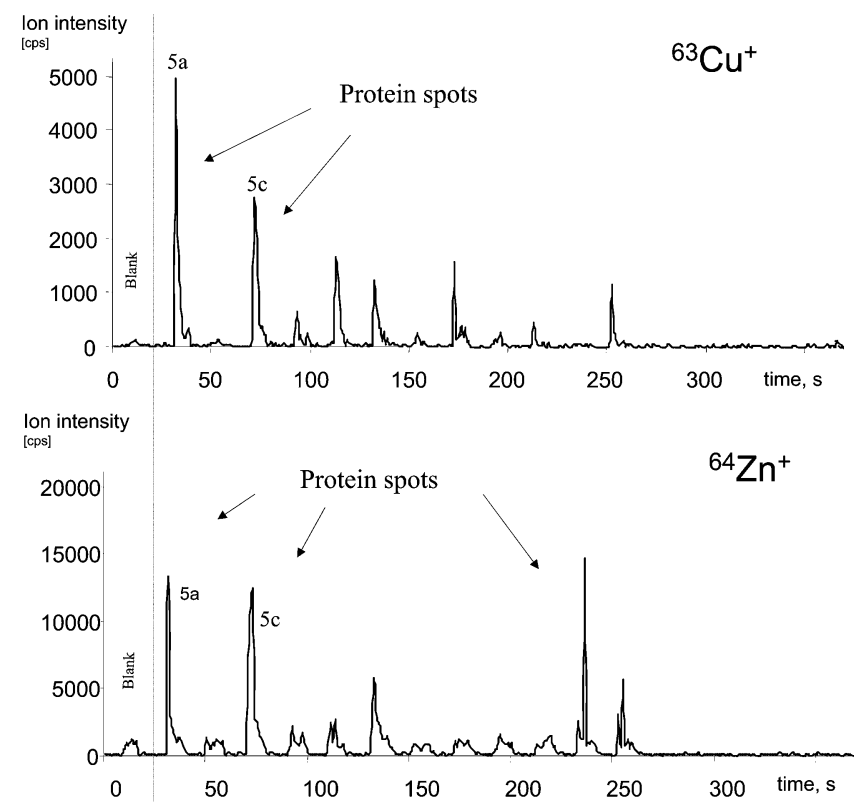

Figure 3. Transient signals for ${ }^{63} \mathrm{Cu}^{+}$and ${ }^{64} \mathrm{Zn}^{+}$in protein spots of human brain sample (cut 5) separated by 2-dimensional gel electrophoresis measured by sector field LA-ICPMS.

Figure 6), followed by spot $6 \mathrm{~g}$ with $2200 \mathrm{cps}$. This finding also correlates with the occurrence of ${ }^{31} \mathrm{P}^{+},{ }^{63} \mathrm{Cu}^{+}$, and ${ }^{64} \mathrm{Zn}^{+}$ion intensities in both protein spots. It is interesting to note that only in protein spot 10 a does uranium appear alone with a ${ }^{238} \mathrm{U}^{+}$ion intensity of $300 \mathrm{cps}$ (the background signal was $<1 \mathrm{cps}$ ).

An advantage of LA-ICPMS is that the screening of separated protein spots in a two-dimensional gel and the qualitative measurements of a multitude of protein spots was performed in just a few hours. This main feature of the screening procedure developed using LA-ICPMS can help to significantly reduce the time required for structure analysis by a preselection of protein spots containing $\mathrm{P}, \mathrm{S}$, and several metals of interest. Table 2 summarizes the results of the qualitative LA-ICPMS analysis of 18 selected protein spots in $2 \mathrm{D}$ gels containing $\mathrm{P}, \mathrm{Cu}, \mathrm{Zn}$, and $\mathrm{U}$ or some of these elements. After a qualitative survey analysis using LA-ICPMS, several protein spots from human brain sample containing $\mathrm{P}, \mathrm{Cu}, \mathrm{Zn}$, and $\mathrm{U}$ can be analyzed by MALDI-FTICRMS with high mass accuracy and mass resolution. But the denaturing and reducing conditions (denaturing agent, sodium dodecyl sulfate, SDS) during the separation of proteins in the second dimension partly releases the naturally bound metal ions. Recently, it was demonstrated in tracer experiments that stable metal-protein complexes can survive denaturing and reducing conditions. ${ }^{19}$ Furthermore, in this work, it was shown that certain proteins can accumulate metal ions during the tracer experiments (e.g., new Zn- and Fe-containing proteins were detected). ${ }^{19}$ The detection of metals at low concentration range in a protein spot by LA-ICPMS also indicates the ability of the protein to bind metal ions during washing steps with contaminants or, for example, during silver staining. ${ }^{14}$ In contrast, the phosphorus is covalently bound to the protein and will not be removed by the electrophoretic procedure. To avoid dephosphorylation of the proteins by phosphatases, a mixture of phosphatase inhibitors was added throughout the isolation and the lysis of human brain sample.

Transient signals of ${ }^{31} \mathrm{P}^{+},{ }^{63} \mathrm{Cu}^{+},{ }^{64} \mathrm{Zn}^{+}$, and ${ }^{238} \mathrm{U}^{+}$in several cuts of $2 \mathrm{D}$ gel measured by LA-ICPMS are demonstrated in Figures $2-7$. Figure 2 shows transient signals for the detection of phosphorylated proteins for cuts 3 and 5 . The transient signals of ${ }^{31} \mathrm{P}^{+}$in selected protein spots in the cut of $2 \mathrm{D}$ gel are shown as a function of measuring time using LA-ICPMS. Due to relatively high background intensity at mass $31 \mathrm{u}$ in these measurements (of about 200-400 cps), it is sometimes difficult to detect phosphorus in protein spots. The highest ${ }^{31} \mathrm{P}^{+}$ion intensity from these cuts was observed in protein spots $3 \mathrm{n}$ and $5 \mathrm{a}$. Mostly higher ion intensities at lower background were observed for ${ }^{63} \mathrm{Cu}^{+}$and ${ }^{64} \mathrm{Zn}^{+}$, in comparison to ${ }^{31} \mathrm{P}^{+}$in the investigated phosphoproteins, as demonstrated for cut 5 (e.g., in proteins $5 \mathrm{a}$ and $5 \mathrm{c}$ ) of $2 \mathrm{D}$ gel of human brain sample. In Figure 3 , transient signals of ${ }^{63} \mathrm{Cu}^{+}$ and ${ }^{64} \mathrm{Zn}^{+}$were measured by LA-ICPMS in several protein spots of cut 5 . In protein spot $5 \mathrm{a}$, all analytes of interest were detected. In addition, ${ }^{238} \mathrm{U}^{+}$with, in general, lower ion intensity was found in individual protein spots ( $3 \mathrm{~b}, 3 \mathrm{f}, 3 \mathrm{k}$, and $5 \mathrm{a}$ ), whereby the background signal at mass $238 \mathrm{u}$ was the lowest of all analytes studied. In cut 2 , only in one protein spot $(2 \mathrm{~g})$ were $\mathrm{P}, \mathrm{Cu}$, and $\mathrm{Zn}$ with remarkable ion intensities detected simultaneously (see Figure 4). Other protein spots contained only $\mathrm{Cu}$ and $\mathrm{Zn}$ (21 and $2 \mathrm{~m})$. No significant uranium ion intensities were measured in any proteins (cut 2); however, ${ }^{238} \mathrm{U}^{+}$with ion intensities of several hundred cps (counts per second) was measured in spots $9 \mathrm{~b}$ and $9 \mathrm{e}$ (see Figure 5). The occurrence of uranium in protein spot $9 \mathrm{~b}$ correlates with a high ${ }^{31} \mathrm{P}^{+}$intensity. In protein spot $9 \mathrm{~d}$, significantly lower ${ }^{31} \mathrm{P}^{+}$intensity was measured, but high ${ }^{63} \mathrm{Cu}^{+}$and ${ }^{64}$ $\mathrm{Zn}^{+}$intensities were also found. In Figure 6, transient signals of ${ }^{31} \mathrm{P}^{+},{ }^{63} \mathrm{Cu}^{+},{ }^{64} \mathrm{Zn}^{+}$, and ${ }^{238} \mathrm{U}^{+}$are summarized, and only in spot 11e were all elements measured simultaneously with relatively high ion intensities. Protein spots 11a and 11d contained P and $\mathrm{Cu}$, as well as $\mathrm{Zn}$. Figure 7 shows transient signals for cut 13 . In the phosphoproteins (spots 131 and $13 \mathrm{c}$ ), ${ }^{63} \mathrm{Cu}^{+},{ }^{64} \mathrm{Zn}^{+}$and ${ }^{238} \mathrm{U}^{+}$ were also detected by LA-ICPMS. 

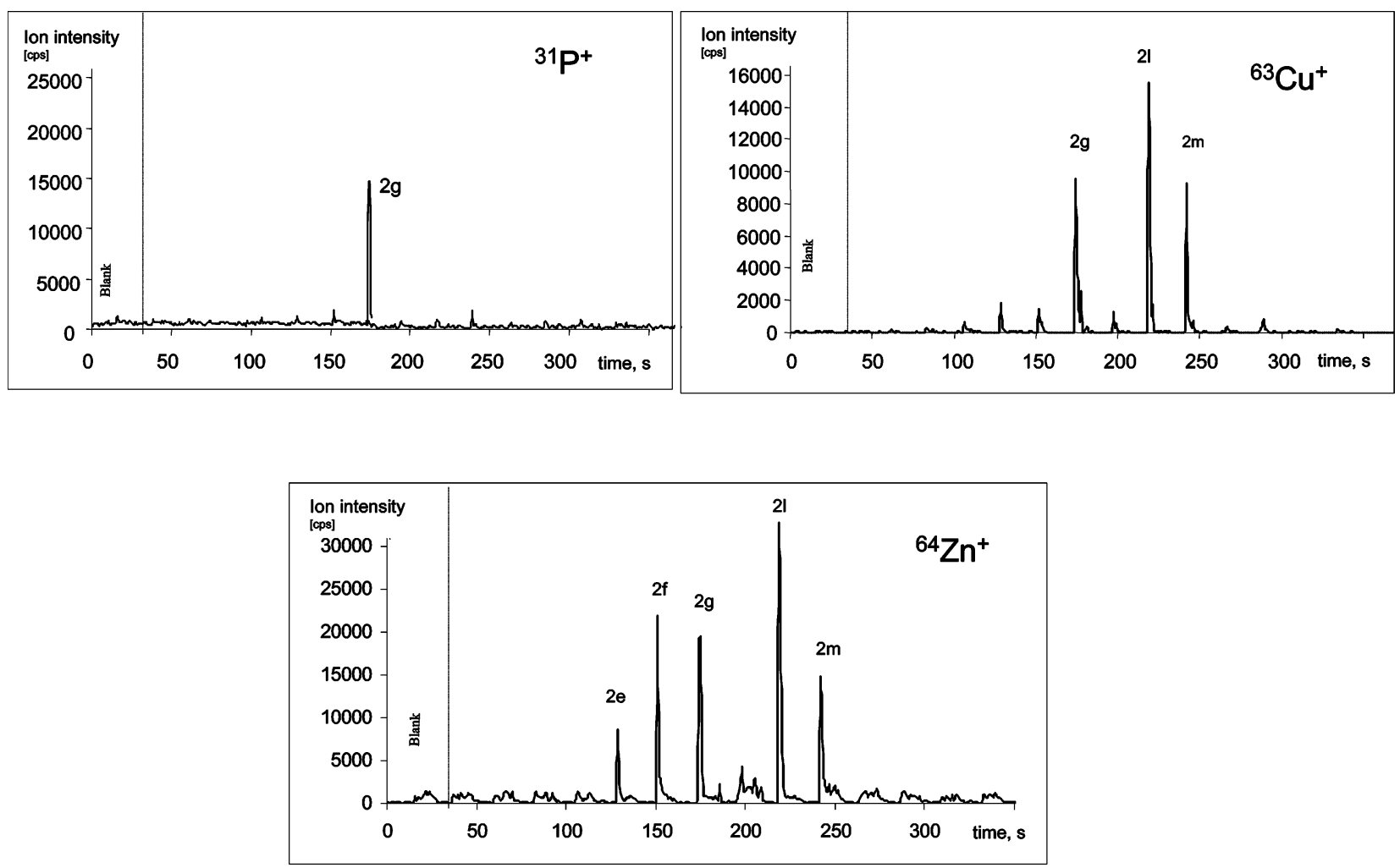

Figure 4. Transient signals for ${ }^{31} \mathrm{P}^{+},{ }^{63} \mathrm{Cu}^{+}$, and ${ }^{64} \mathrm{Zn}^{+}$in protein spots of human brain sample (cut 2) separated by 2 -dimensional gel electrophoresis measured by sector field LA-ICPMS.
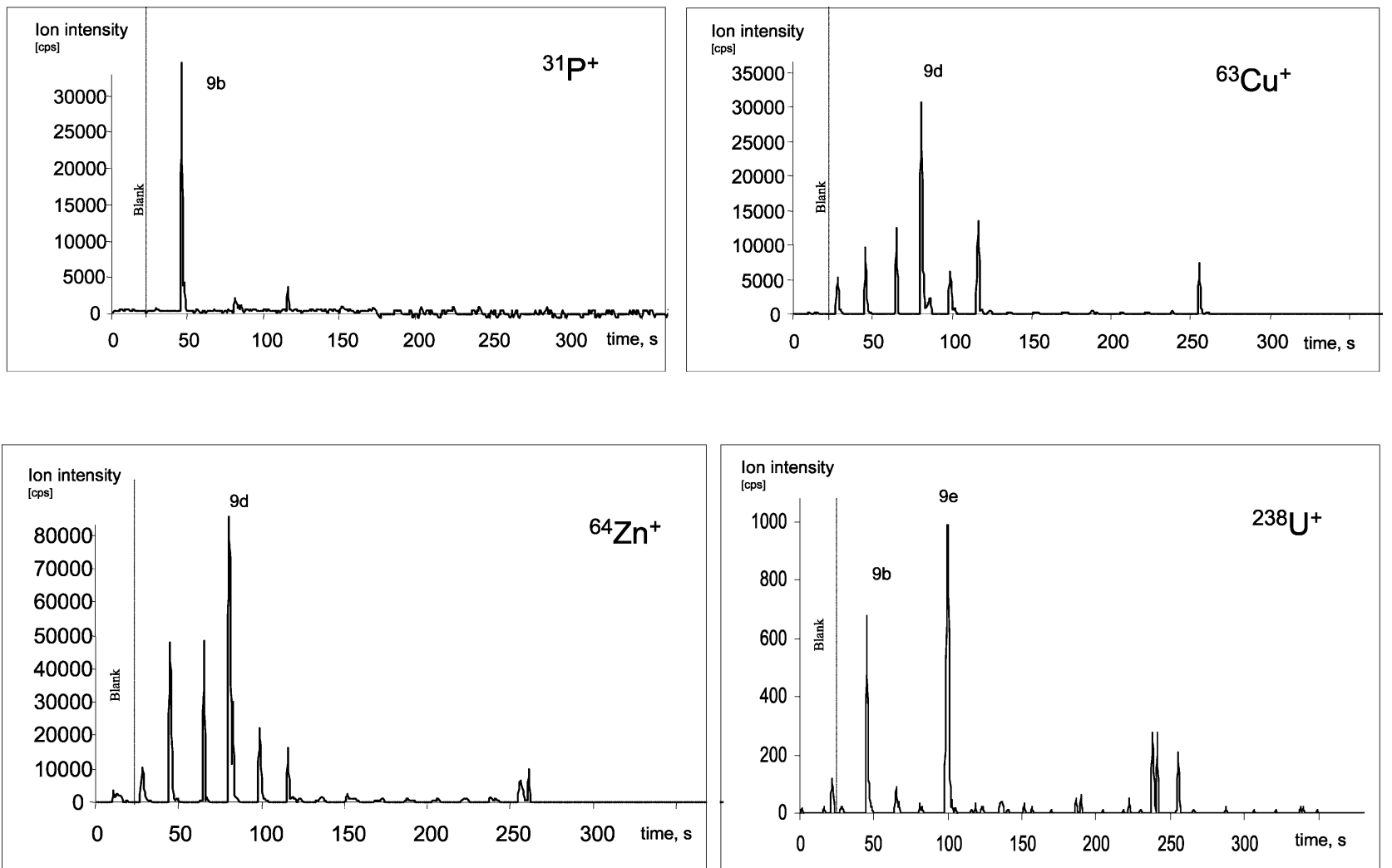

Figure 5. Transient signals for ${ }^{31} \mathrm{P}^{+},{ }^{63} \mathrm{Cu}^{+}, 64 \mathrm{Zn}^{+}$, and ${ }^{238} \mathrm{U}^{+}$in protein spots of human brain sample (cut 9 ) separated by 2 -dimensional gel electrophoresis measured by sector field LA-ICPMS.

Identification of Proteins by High-Resolution MALDIFTICR-MS. We attempted to identify individual protein spots from human brain separated by 2D gel electrophoresis by biopolymer mass spectrometry using MALDI-FTICR-MS after excision from 2D gel and tryptic digestion. The methods for the identification and characterization of proteins by mass spectrometry generally 

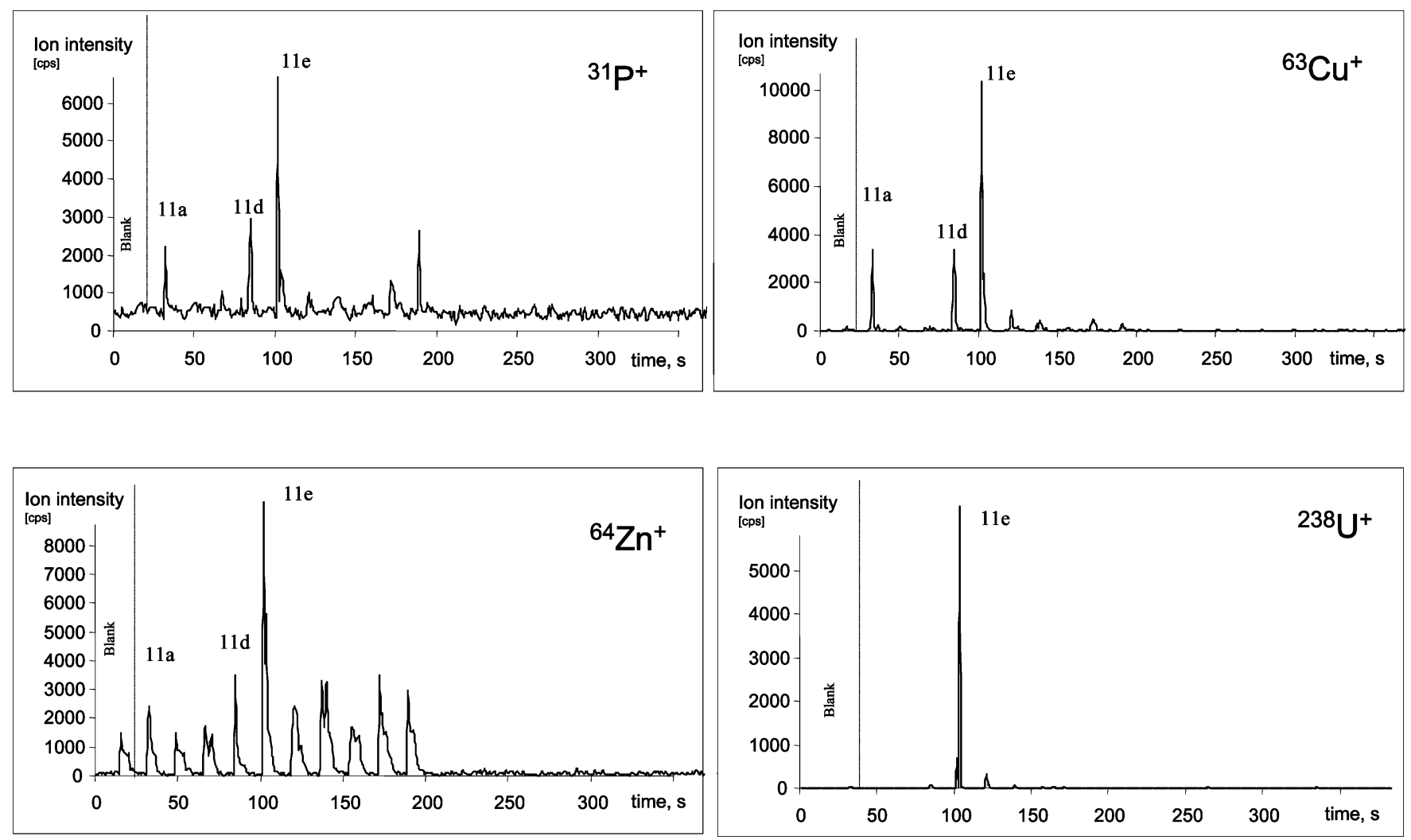

Figure 6. Transient signals for ${ }^{31} \mathrm{P}^{+},{ }^{63} \mathrm{Cu}^{+},{ }^{64} \mathrm{Zn}^{+}$, and ${ }^{238} \mathrm{U}^{+}$in protein spots of human brain sample (cut 11) separated by 2 -dimensional gel electrophoresis measured by sector field LA-ICPMS.

Table 2. Qualitative Results of P, Cu, Zn, and U
Detection in Selected Protein Spots by LA-ICPMS
$\begin{array}{ccccccccccc}\text { spot ID } & \mathrm{P} & \mathrm{Cu} & \mathrm{Zn} & \mathrm{U} & \text { spot ID } & \mathrm{P} & \mathrm{Cu} & \mathrm{Zn} & \mathrm{U} \\ & & & & & & & & & \\ \mathrm{l} & + & + & + & (+) & 9 \mathrm{~d} & (+) & ++ & ++ & (+) \\ 2 \mathrm{f} & - & (+) & + & - & 9 \mathrm{f} & + & + & + & - \\ 2 \mathrm{~g} & ++ & ++ & ++ & (+) & 10 \mathrm{j} & + & ++ & ++ & (+) \\ 2 \mathrm{l} & - & ++ & ++ & - & 11 \mathrm{a} & + & + & + & - \\ 4 \mathrm{~m} & - & ++ & + & (+) & 11 \mathrm{~d} & + & + & + & - \\ 5 \mathrm{a} & + & + & ++ & + & 11 \mathrm{e} & + & + & ++ & + \\ 6 \mathrm{~g} & + & + & + & + & 12 \mathrm{a} & ++ & ++ & + & + \\ 7 \mathrm{~d} & - & + & ++ & - & 12 \mathrm{c} & - & - & + & - \\ 7 \mathrm{e} & ++ & + & + & + & 13 \mathrm{c} & + & + & + & + \\ 8 \mathrm{c} & + & + & + & - & 131 & + & + & + & + \\ 9 \mathrm{~b} & ++ & + & ++ & + & 14 \mathrm{c} & + & ++ & ++ & + \\ 9 \mathrm{c} & - & + & ++ & (+) & & & & & \end{array}$

${ }^{a}++,>10000$ cps. $^{b}(+)$, signal near the background. ${ }^{c}-$, not detected.

include the following analytical procedures: (i) degradation of the protein into small peptides by enzymatic treatment and (ii) differential peptide mapping using different databases. ${ }^{27}$ The development of FTICR mass spectrometry has recently enabled a breakthrough in the high-resolution mass spectrometric structure analysis of proteins using MALDI ionization; ;,19 in combination with $2 \mathrm{D}$ gel electrophoresis, the high (sub-parts-per-million) mass determination accuracy and isotopic fine structure by FTICR-MS provides particular advantages for the identification of proteins of medium and low abundance. The primary structure of selected proteins can be directly identified after tryptic digestion by MALDI-FTICR-MS and afterward a database search using, for

(27) Swiss-Prot Protein Knowledgebase: http://www.espasy.ch/sprot/. example, Mascot peptide mass fingerprint ${ }^{28}$ for protein identification. Table 3 summarizes the results of the identification and quantification of sulfur of several proteins using MALDI-FTICRMS. For example, spot $3 \mathrm{n}$ was identified as $\alpha$-internexin (containing six cystein residues) with a molecular weight of $55.4 \mathrm{kDa}$. Spot $4 \mathrm{n}$ was identified as creatine kinase $\beta$-chain (containing 16 cystein residues) and $3 f$ as vacuolar ATP synthase catalytic subunit A containing 29 cystein residues. The observed molecular weight of proteins in the analyzed protein in the $2 \mathrm{D}$ gel corresponds to the calculated value.

Determination of Concentrations and Element Ratios in Protein Spots in 2D Gel after Separation by Gel Electrophoresis Using LA-ICPMS. LA-ICPMS is a promising and fast surface analytical technique for the direct microlocal analysis of protein spots in a two-dimensional gel to demonstrate the occurrence of $\mathrm{P}, \mathrm{Cu}, \mathrm{Zn}$, and other elements (such as $\mathrm{U}$ ).

${ }^{31} \mathrm{P}^{+}$ion intensities were measured by LA-ICPMS, and the data were quantified in the protein spots identified by MALDI-FTICRMS using sulfur as the internal standard element. For example, in protein spot 21 (tubulin $\beta$-4 chain) with a molecular weight of $50.4 \mathrm{kDa}$, the phosphorus concentration was determined by combination of organic and atomic mass spectrometry to be 0.12 $\mathrm{mg}^{-1}$. The phosphorylation state was determined in protein spot 21 to be 6 . In Table 4 , the results of quantification for $\mathrm{P}, \mathrm{Cu}$, and $\mathrm{Zn}$ on selected protein spot 21 and the detection limits measured in the gel blank (silver-stained) after digestion are given.

The problem in the evaluation of analytical data was the high background of sulfur due to contamination of $2 \mathrm{D}$ gel during the

(28) Mascot-Database: http://www.matrixscience.com/. 

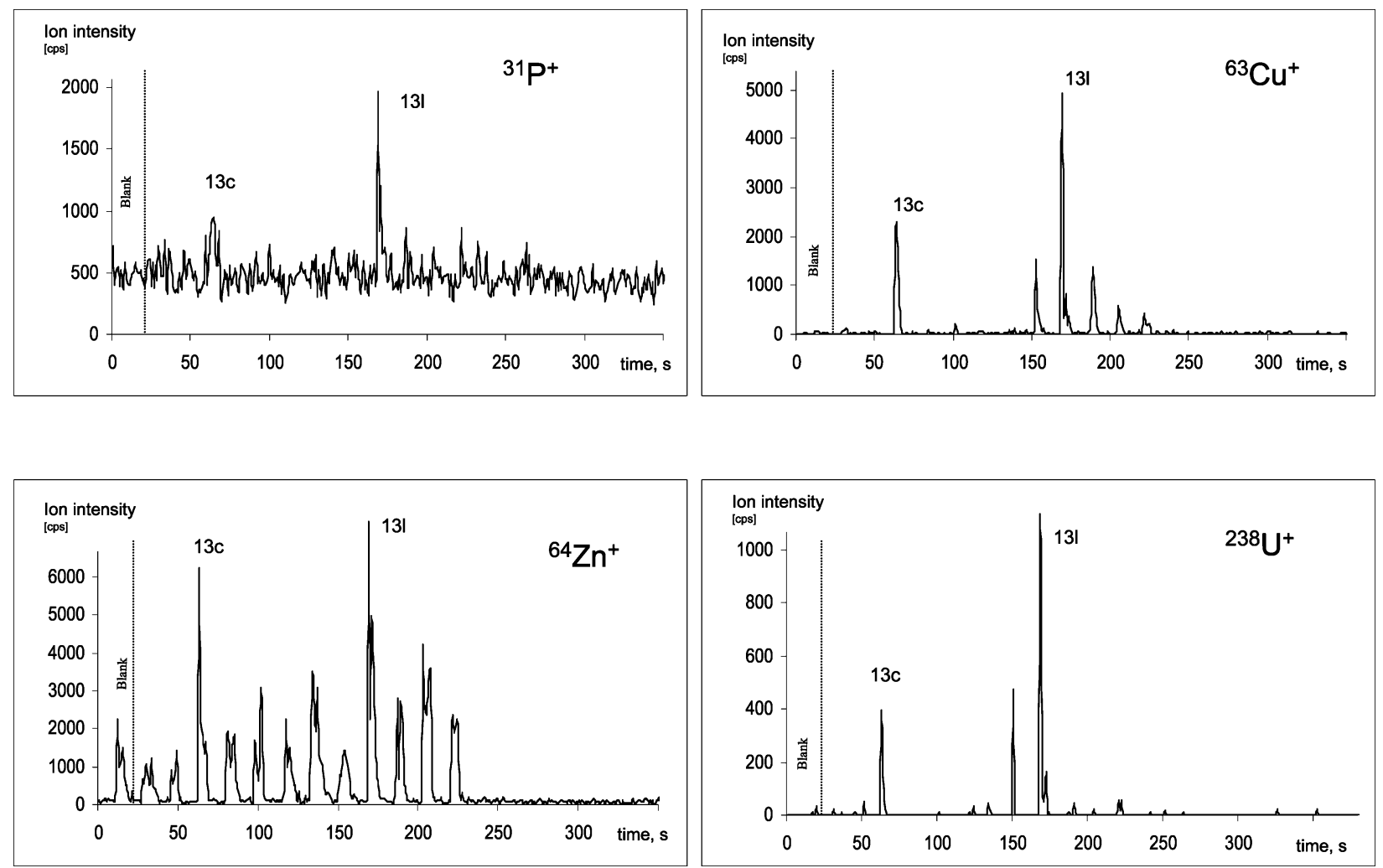

Figure 7. Transient signals for ${ }^{31} \mathrm{P}^{+}, 63 \mathrm{Cu}^{+},{ }^{64} \mathrm{Zn}^{+}$, and ${ }^{238} \mathrm{U}^{+}$in protein spots of human brain sample (cut 13) separated by 2 -dimensional gel electrophoresis measured by sector field LA-ICPMS.

\begin{tabular}{|c|c|c|c|c|c|}
\hline spot & protein & $\begin{array}{c}\mathrm{MW}_{\text {theor }} \\
(\mathrm{kDa})\end{array}$ & $\begin{array}{l}\mathrm{MW}_{\text {exptl }} \\
(\mathrm{kDa})\end{array}$ & $\begin{array}{l}\text { cysteine } \\
\text { residues }\end{array}$ & $\begin{array}{l}\mathrm{S} \\
\mathrm{mg} / \mathrm{g}\end{array}$ \\
\hline $2 \mathrm{~g}$ & tubulin $\alpha-4$ chain & 49.9 & $\sim 50$ & 24 & 12.6 \\
\hline 21 & tubulin $\beta$ - 4 chain & 4 & $\sim 50$ & 27 & 16.8 \\
\hline $3 \mathrm{f}$ & $\begin{array}{l}\text { vacuolar ATP synthase } \\
\text { catalytic subunit A, } \\
\text { ubiquitous isoform }\end{array}$ & 68.3 & $\sim 69$ & 29 & 17.2 \\
\hline $3 n$ & $\alpha$-internexin & 55.4 & $\sim 55$ & 6 & 3.2 \\
\hline $4 \mathrm{~m}$ & GFAP protein & & $\sim$ & 12 & 6.2 \\
\hline $4 \mathrm{n}$ & creatine kinase, $\beta$ chain & 4 & $\sim 4$ & 16 & 7.4 \\
\hline $4 p$ & $\mathrm{ACTB}$ protein & 40. & $\sim 40$ & 22 & 11.9 \\
\hline $4 \mathrm{q}$ & ACTB protein & 40. & $\sim 40$ & 22 & 12.4 \\
\hline 40 & creatine kinase, $\beta$ chain & 42. & $\sim 43$ & 16 & 7.0 \\
\hline $5 a$ & $\begin{array}{l}\text { vacuolar ATP synthase B, } \\
\text { brain isoform }\end{array}$ & 56.5 & $\sim 57$ & 22 & 12.1 \\
\hline $7 \mathrm{f}$ & $\begin{array}{l}\text { chain B, human heart } \\
\text { L-lactate dehydrogenase } \\
\text { H chain }\end{array}$ & 36.5 & $\sim 37$ & 14 & 75.3 \\
\hline $12 \mathrm{f}$ & peroxiredoxin 2 isoform b & 16.0 & $\sim 16$ & 2 & 1.2 \\
\hline
\end{tabular}

Table 4. Quantitative Results of the Protein Spot 21 (Tubulin $\beta-4$ Chain) Measured by Combination of MALDI-FTICR-MS and LA-ICPMS

\begin{tabular}{llcccc} 
& \multicolumn{4}{c}{ concn, $\mathrm{mg} \mathrm{g}^{-1}$} & \\
\cline { 2 - 5 } \multicolumn{1}{c}{ protein } & \multicolumn{1}{c}{$\mathrm{P}$} & $\mathrm{S}$ & $\mathrm{Cu}$ & $\mathrm{Zn}$ & phosphorylation \\
tubulin $\beta$-4 chain & 0.12 & 17.1 & 5.9 & 8.8 & 6 \\
LOD, mg g $^{-1}$ & 0.00127 & 1.289 & 0.0291 & 0.063 & \\
\hline
\end{tabular}

gel electrophoresis with SDS, which results in a high detection limit of $\sim 1.3 \mathrm{mg} \mathrm{g}^{-1}$.

LA-ICPMS can be applied also for determination of stoichiometry in selected proteins by measuring phosphorus- and metalto-sulfur ratios. Some results of element ratios in selected protein
Table 5. Phosphorus- and Metal-to-Sulphur Element Ratios in Some Selected Proteins Measured by LA-ICP-SFMS

\begin{tabular}{lllll} 
spot & $\mathrm{P} / \mathrm{S}$ & $\mathrm{Cu} / \mathrm{S}$ & $\mathrm{Zn} / \mathrm{S}$ & $\mathrm{U} / \mathrm{S}$ \\
$1 \mathrm{e}$ & 0.014 & 0.14 & 0.59 & \\
$2 \mathrm{f}$ & & 0.49 & 0.96 & \\
$2 \mathrm{l}$ & & 0.33 & 0.5 & \\
$3 \mathrm{k}$ & 0.077 & 0.27 & 0.49 & \\
$5 \mathrm{c}$ & 0.022 & 0.21 & 0.84 & \\
$6 \mathrm{j}$ & 0.14 & 0.11 & 0.51 & 0.37 \\
$6 \mathrm{o}$ & 0.77 & 0.43 & 0.33 & \\
$9 \mathrm{f}$ & 0.14 & 0.16 & 0.51 & 0.07 \\
$11 \mathrm{e}$ & 0.07 & 0.04 & 0.098 & \\
\hline
\end{tabular}

spots are summarized in ratios in Table 5 . All element ratios are $<1$.

Selected protein spots in 2D gel containing uranium were identified after tryptic digestion (e.g., $\alpha$-internexin or vacuolar synthase ATP with molecular weights of 55.53 and $68.30 \mathrm{KDa}$, respectively). The mass spectrum of spot $3 \mathrm{n}$ ( $\alpha$-internexin) with the identified peptides is shown in Figure 8. The protein could be identified with a good high score of 213 from the mascot database (www.matrixscience.com). Three modified peptides containing, in part, $\mathrm{P}, \mathrm{Fe}, \mathrm{Zn}$, and $\mathrm{Cu}$ could be identified. The phosphorylated peptide $\mathrm{K}^{448}-\mathrm{K}^{461}\left(\mathrm{E}^{449}-\mathrm{K}^{462}\right)$ contains a phosphoserine at $\mathrm{S}^{460}$ or $\mathrm{S} .{ }^{456}$ In Figure 9, the mass spectrum of spot $4 \mathrm{~m}$ (GFAP, glial fibrillary acidic protein) is shown. In this protein, no modifications could be found by using MALDI-FTICR-MS.

Additional isotope ratio measurements of uranium in Ucontaining protein spots showed, as expected, that all of them contained uranium of natural isotopic composition. To study 


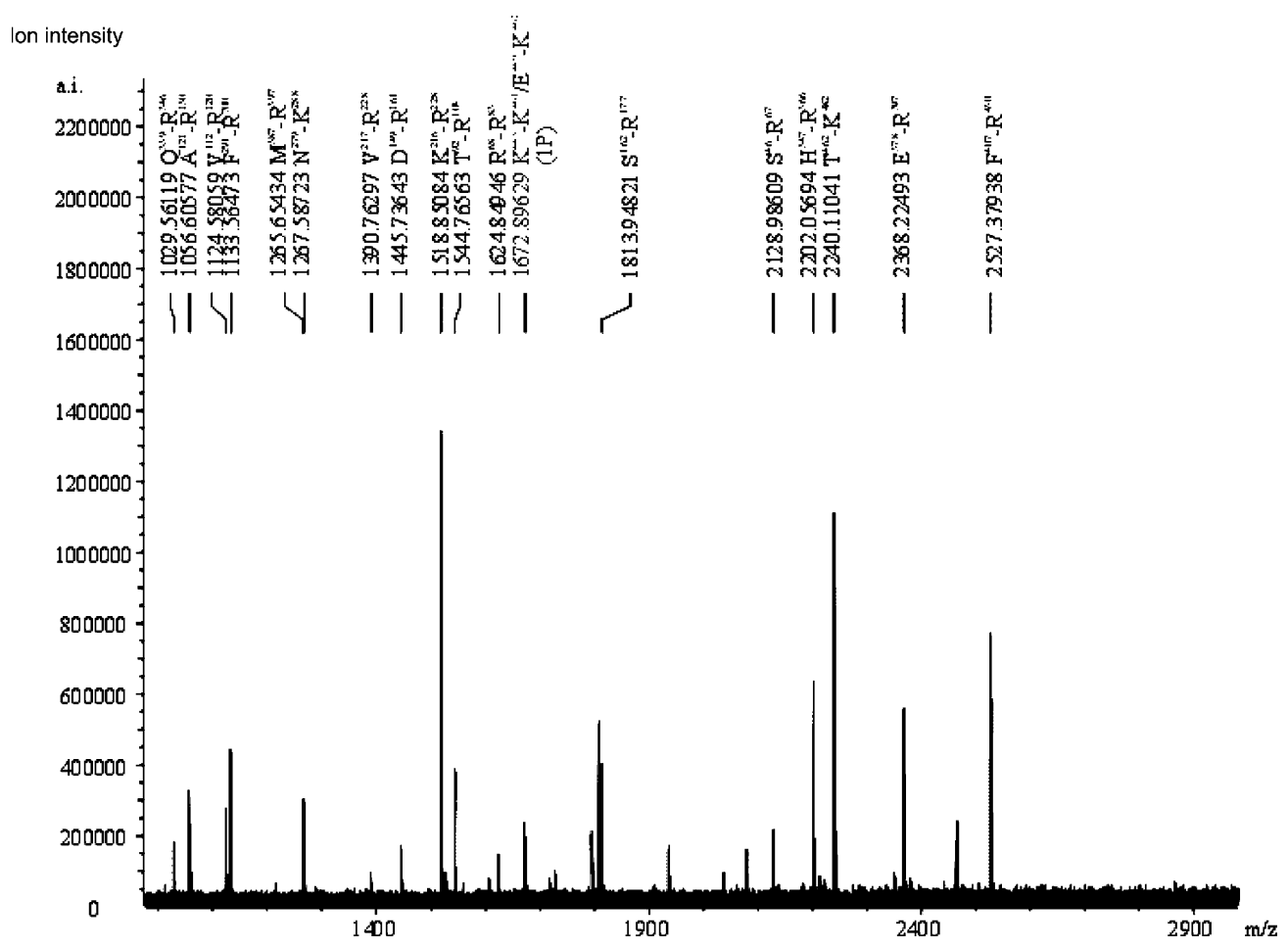

Figure 8. MALDI-FTICR mass spectrum of protein spot $3 n$ ( $\alpha$-internexin) with the identified peptides and phosphopeptide $K^{448}-K^{461}\left(E^{449}-\right.$ $\mathrm{K}^{462}$ ) using Mascot database ${ }^{28}$ for peptide mass fingerprint for protein identification.

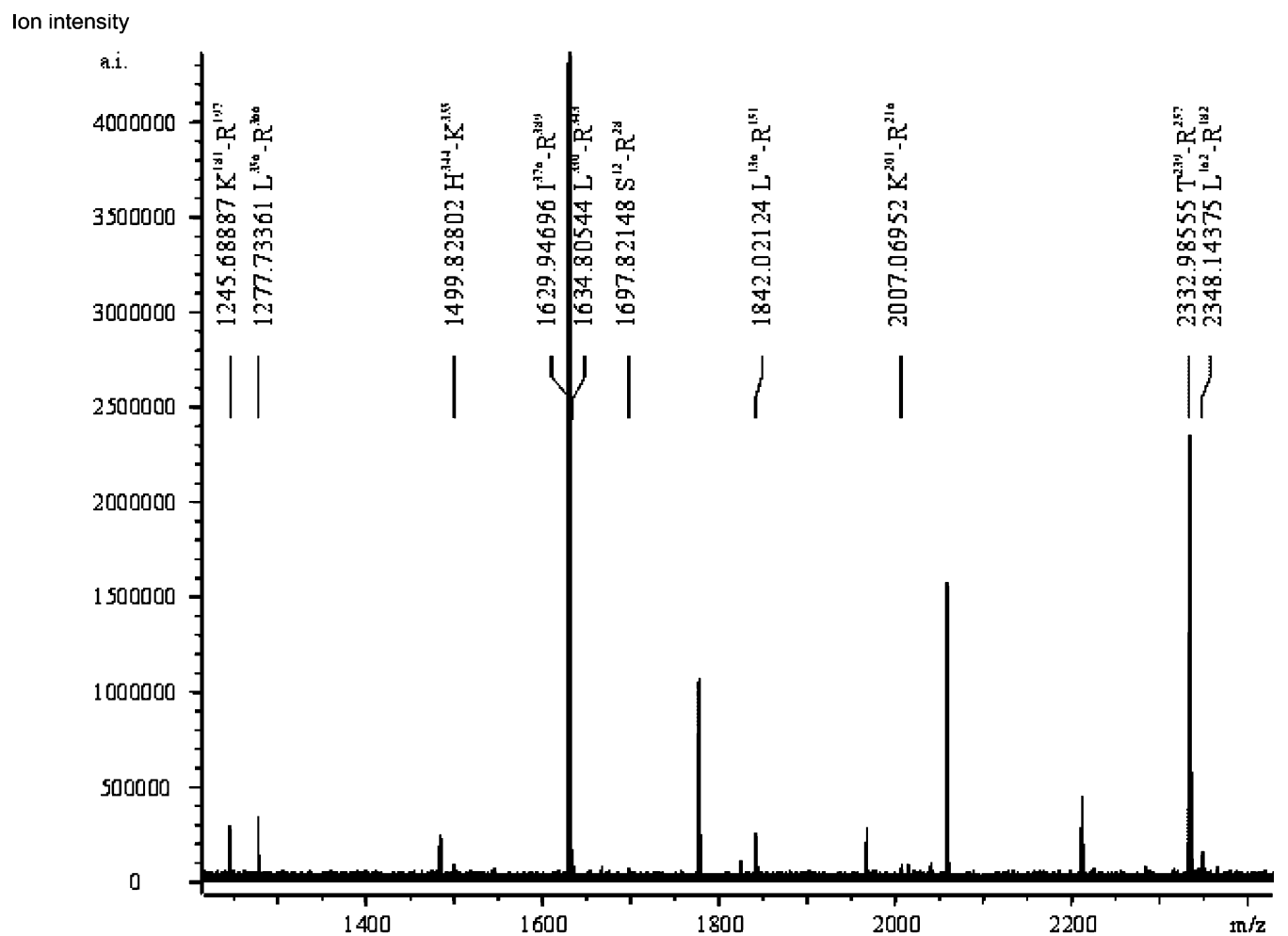

Figure 9. MALDI-FTICR mass spectrum of protein spot $4 \mathrm{~m}$ (GFAP protein) with the identified peptides using Mascot database ${ }^{28}$ for peptide mass fingerprint for protein identification.

uranium-binding proteins, tracer experiments were performed using ${ }^{235} \mathrm{U}$-enriched uranium whereby the isotope tracer was doped to the brain sample before and after 2D gel electrophoresis. Protein spots with an increased ${ }^{235} \mathrm{U} /{ }^{238} \mathrm{U}$ isotope ratio were detected by LA-ICPMS in gels, for example, of Alzheimer-diseased brain samples doped with ${ }^{235} \mathrm{U}$-enriched uranium after $2 \mathrm{D}$ gel electrophoresis. ${ }^{24}$ This result demonstrates that certain proteins are able to accumulate uranium. The detection limit of LA-ICPMS for uranium in separated protein spots in 2D gels was found to be $10 \mathrm{ng} \mathrm{g}^{-1} \cdot 29$

Future work will be focused on development of isotope dilution analysis via on-line solution-based calibration in LA-ICPMS using 
a micronebulizer inserted directly into the cooled laser ablation chamber..$^{30}$

\section{CONCLUSION}

In the present study, 176 well-separated protein spots in twodimensional gels after 2D gel electrophoresis were screened with respect to the occurrence of $\mathrm{P}, \mathrm{Cu}, \mathrm{Zn}$, and $\mathrm{U}$ by LA-ICPMS as a microlocal analytical technique with multielement capability. Phosphorus and metal-containing proteins were detected in short analysis times using LA-ICPMS with a cooled laser ablation chamber. The combination of high-resolution MALDI-FTICR-MS and LA-ICPMS represents a powerful tool for the identification of phosphorylated and metal-containing human brain proteins and determination of phosphorus and metal content in selected

(29) Becker, J. S.; Zoriy, M.; Pickhardt, C.; Becker, J. S.; Przybylski, M. Determination of Long-Lived Radionuclides by LA-ICPMS; 7th European Workshop on Laser Ablation, Sheffield, UK, 2004.

(30) Becker, J. S.; Zoriy, M.; Pickhardt, C.; Palomero-Gallegher, N.; Zilles, K. Anal. Chem. 2005, 77, 3208. proteins. The complementary data from the two methods are particularly valuable in the case of multiple modifications for which no other currently available technique will provide corresponding protein information. The most important problem for the determination of phosphorus and other elements in the gel is possible contamination during sample preparation or by staining. Future work will focus on improving the screening technique using a laser ablation system with better lateral resolution and development of further quantification procedures.

\section{ACKNOWLEDGMENT}

Work at the University of Konstanz was supported by the Deutsche Forschungsgemeinschaft, Bonn, Germany (BiopolymerMS). The first author is very grateful to H.-J. Dietze (Juelich, Germany) for valuable discussions.

Received for review April 18, 2005. Accepted July 13, 2005.

AC0506579 